Article

\title{
Covalently Immobilized Battacin Lipopeptide Gels with Activity against Bacterial Biofilms
}

\author{
Gayan Heruka De Zoysa ${ }^{1}{ }^{(0)}$, Kelvin Wang ${ }^{2}$, Jun Lu ${ }^{2}{ }^{-}$, Yacine Hemar ${ }^{3}$ and \\ Vijayalekshmi Sarojini ${ }^{1,4, *}$ \\ 1 School of Chemical Sciences and the Centre for Green Chemical Science, The University of Auckland, \\ Auckland 1142, New Zealand; heru.de-zoysa@auckland.ac.nz \\ 2 School of Science, Auckland University of Technology, 34 St. Paul Street, Auckland 1142, New Zealand; \\ kelvin.wang@aut.ac.nz (K.W.); jun.lu@aut.ac.nz (J.L.) \\ 3 Department of Biotechnology and Food Engineering, Guangdong Technion Israel Institute of Technology, \\ Shantou 515063, China; yacine.hemar@gtiit.edu.cn \\ 4 The MacDiarmid Institute for Advanced Materials and Nanotechnology, Wellington 6140, New Zealand \\ * Correspondence: v.sarojini@auckland.ac.nz; Tel.: +64-9-9233387
}

Academic Editor: Paul Robert Hansen

Received: 1 November 2020; Accepted: 9 December 2020; Published: 15 December 2020

\begin{abstract}
Novel antibiotic treatments are in increasing demand to tackle life-threatening infections from bacterial pathogens. In this study, we report the use of a potent battacin lipopeptide as an antimicrobial gel to inhibit planktonic and mature biofilms of S. aureus and P. aeruginosa. The antimicrobial gels were made by covalently linking the $N$-terminal cysteine containing lipopeptide (GZ3.163) onto the polyethylene glycol polymer matrix and initiating gelation using thiol-ene click chemistry. The gels were prepared both in methanol and in water and were characterised using rheology, Fourier transform infrared (FT-IR) spectroscopy and scanning electron microscopy (SEM). Antibacterial and antibiofilm analyses revealed that the gels prepared in methanol have better antibacterial and antibiofilm activity. Additionally, a minimum peptide content of $0.5 \mathrm{wt} \%$ (relative to polymer content) is required to successfully inhibit the planktonic bacterial growth and disperse mature biofilms of P. aeruginosa and S. aureus. The antibacterial activity of these lipopeptide gels is mediated by a contact kill mechanism of action. The gels are non-haemolytic against mouse red blood cells and are non-cytotoxic against human dermal fibroblasts. Findings from this study show that battacin lipopeptide gels have the potential to be developed as novel topical antibacterial agents to combat skin infections, particularly caused by $S$. aureus.
\end{abstract}

Keywords: antimicrobial lipopeptides; antimicrobial hydrogels; bacterial biofilm inhibition; non haemolytic; non-cytotoxic

\section{Introduction}

Antimicrobial resistance is one of the biggest health risks faced by modern society. As a result, we are increasingly reliant on "last-resort" antibiotics as "first-line" treatments against multi-drug resistant (MDR) pathogens. To further exacerbate this problem, several of these MDR pathogens also aggregate and colonise surfaces, forming bacterial biofilms that are up to 1000 times more resistant to antibiotic treatments than their planktonic counterparts [1]. An indirect effect of antibiotic resistance is the greater financial burden on patients, due to prolonged hospitalisation periods and the necessity to rely on more expensive antibiotic treatments. According to the 2013 report published by the Centre for Disease Control and Preventions each year in the United States of America, at least 2 million people become infected with resistant bacterial pathogens and at least 23,000 people die as a direct result of MDR bacterial infections [2]. 
Antimicrobial peptides (AMP), particularly lipopeptides, have been gaining attention as attractive alternatives to antibiotics, mainly due to their unique membrane lytic mechanism of action that reduces the chances of bacterial resistance and their ability to inhibit MDR pathogens and bacterial biofilms [3-7]. Battacin is a recently discovered cyclic lipopeptide with potent in vitro and in vivo antibacterial activity against MDR P. aeruginosa and E. coli [8]. Through extensive structure-activity relationship studies we have previously reported on several potent membrane-lytic linear battacin analogues with broad spectrum antibacterial activity against Gram negative (P. aeruginosa, E. coli, E. amylovora and Pseudomoas syringae pv. actinidae) and Gram positive (S. aureus) bacteria and fungi (C. albicans) [9-13]. Unlike the original cyclic lipopeptide, the synthetic analogues also have the ability to prevent biofilm formation and to disrupt mature biofilms of the above pathogens $[9,13]$. Some of our reported lipoeptide analogues are non-haemolytic $(>1000 \mu \mathrm{M})$ against mouse red blood cells $[9,13]$, non-cytotoxic against human dermal fibroblasts [10] and stable up to $24 \mathrm{~h}$ against serum proteases [12].

We have also immobilised these lipopeptides onto titanium and silicon surfaces, commonly used in medical implants without compromising their antibacterial and anti-biofilm activity against $P$. aeruginosa and E. coli [11]. This encouraging result prompted us to evaluate the potential of these lipopeptides as antimicrobial hydrogels. Hydrogels are three dimensional biomaterials that retain water and are extensively utilised in different medical applications such as in topical antibiotics and for wound dressing. Due to their high-water content, hydrogels provide a moisturized environment to stimulate wound healing. Additionally, the soft consistency of the hydrogel can mimic natural living tissues and prevent secondary infections caused by the entry of microorganisms into the wound [14]. Furthermore, delivery of antimicrobial compounds in the form of hydrogels can provide higher localised concentration of the biocide at the source of infection causing reduced systematic toxicity, and preventing chances of bacterial resistance [14].

Hydrogels can be produced by either self-assembly of molecules, dictated by non-covalent interactions such as hydrophobic forces and $\pi-\pi$ stacking or covalent crosslinking using different polymers (e.g., chitosan, alginate and poly(ethylene glycol) methacrylate) [15-19]. We recently reported on ultrashort battacin based lipopeptides that form self-assembling antimicrobial hydrogels with activity against $P$. aeruginosa and S. aureus [10]. One drawback of self-assembling hydrogels is the requirement for high biocide concentration, which makes them an expensive option for drug delivery applications [14,18]. Additionally, non-covalent interactions which trap the self-assembled biocides, can facilitate rapid drug release leading to reduced efficacy. Consequently, antimicrobial compounds with toxicity at higher doses and chances of developing antibacterial resistance are not ideal candidates for self-assembling antibacterial hydrogels $[14,18,19]$. Covalently assembled hydrogels can mitigate these issues. Covalent linkage can precisely control the amount of the antimicrobial agent loaded onto the hydrogel matrix, which reduces systemic toxicity and prevent any biocide leakage from the hydrogel scaffold, leading to longer-term efficiency. This study reports the synthesis, characterisation, and antimicrobial activity of covalently conjugated linear battacin lipopeptide based hydrogels.

\section{Results and Discussion}

\subsection{Hydrogel Design}

We have previously immobilised the $N$-terminal cysteine containing lipopeptide (GZ3.163) onto glass, silicon, and titanium surfaces using polyethylene glycol (PEG) as a linker [11]. PEG based antimicrobial hydrogels have been extensively studied in the literature and PEG based materials are ideal for antibacterial surfaces mainly due to their anti-adhesive property attributed to the high mobility and steric hindrance of the ethylene glycol moieties as well as due to low host immune response [14,19-23]. The hydrogels reported in this study were generated using PEG based polymer as the hydrogel matrix and thiol-ene click chemistry to covalently link the $N$-term cys lipopeptide to the hydrogel network (Scheme 1). Thiol-ene click reaction is highly chemo-selective, has fast reaction 
kinetics, requires mild reaction conditions, can be carried out in inert solvents such as water, and high yields of pure products without the need for chromatographic separation can be achieved [24].

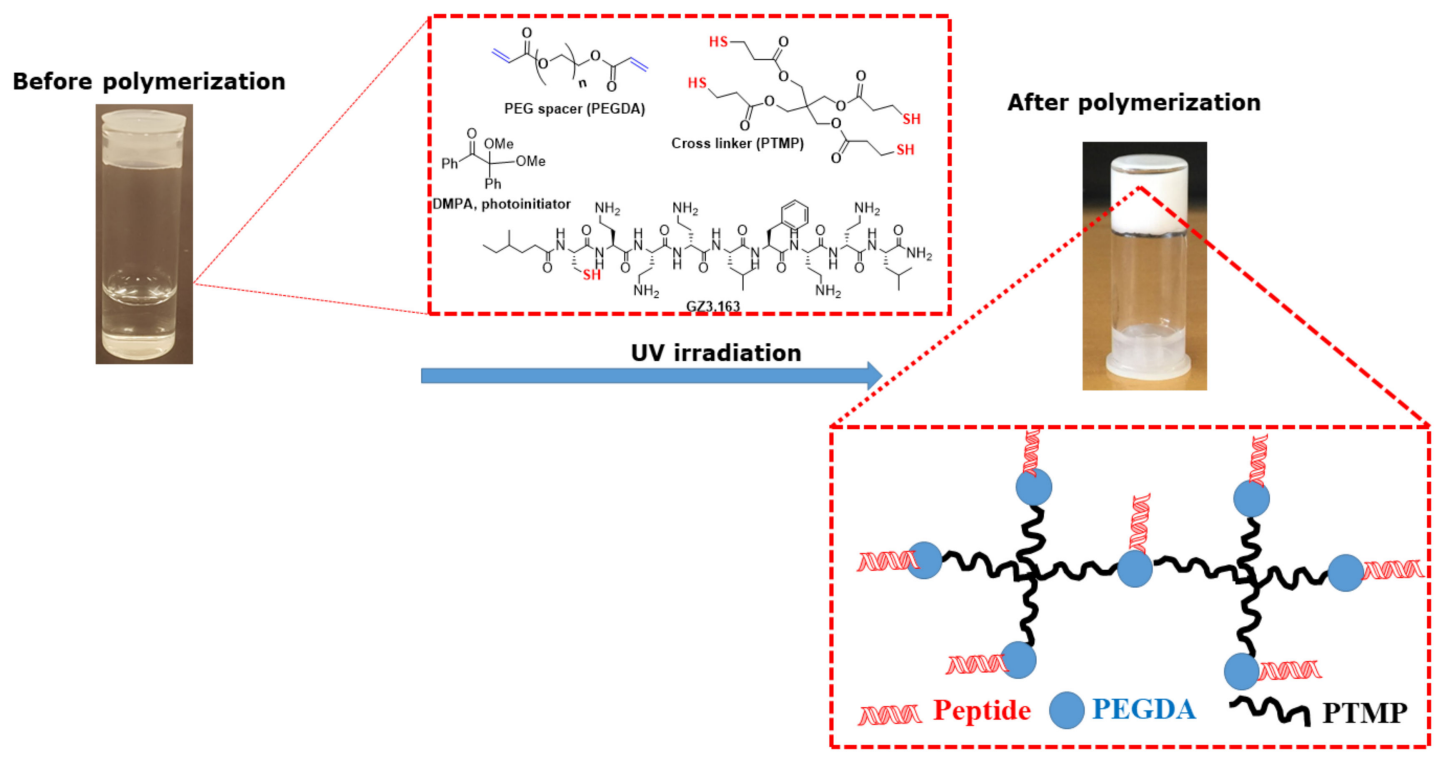

Scheme 1. Antimicrobial lipopeptide gel formation in methanol through covalent photo polymerization under UV irradiation.

The lipopeptide containing hydrogel (0-10 wt\% to the total polymer content) was prepared by mixing the tetra branched thiol crosslinker; PTMP diacrylate spacer, PEGDA, and a catalytic amount of the photoinitiator DMPA. Controlled hydrogel formation was achieved via photopolymerization under UV irradiation to generate reactive radicals, which undergo selective Michael reaction between thiol and acrylate groups resulting in irreversible thioether bond between the lipopeptide and PEG matrix [20,21]. Several groups have utilised this unique thiol-ene photopolymerization reaction for a range of biomedical applications [20-23,25,26]. To the best of our knowledge, only Cleophas et al. have covalently immobilised antimicrobial peptides onto the PEG hydrogel matrix using this chemistry (Scheme 1) [20,21]. In their work, the $N$-terminal cys containing antimicrobial peptide, HHC10 $(0.1 \%$, $0.5 \%, 1 \%$ and $10 \mathrm{wt} \%$ to the total polymer content) was covalently immobilised onto the hydrogel network using thiol-ene photopolymerization [21]. The antibacterial activity of these hydrogels was evaluated against $S$. aureus, S. epidermidis, and E. coli. Only hydrogels carrying the $10 \mathrm{w} t \%$ of the peptide was efficient in eradicating these pathogens [21]. Although the HHC10 peptide is non-haemolytic against the sheep blood cells, the haemolytic activity and cell viability of the peptide conjugated hydrogels have not been reported by the authors $[20,21]$.

As evident from the Scheme 1 images (before and after polymerization), GZ3.163 peptide-gels at $0.1,0.5,1$, and 10 peptide $w t \%$ was successfully generated using thiol-ene photopolymerization. The PEG hydrogel without the peptide (i.e., $0 \%$ peptide weight) was used as the control sample. All samples had very fast gelation kinetics (<60 s) except for the sample containing $10 \%$ wt. of the peptide, which took $10 \mathrm{~min}$ to gelate. The gel samples were initially prepared in methanol as reported by Cleophas et al. [20,21]. We decided to generate these peptide hydrogels $(0,0.1,0.5$, and 1 peptide $\mathrm{wt} \%$ to total polymer content) in water as well in order to more closely mimic physiological conditions. Although GZ3.163 is highly soluble in water, both the PEG spacer and the tetra branched thiol crosslinker are highly insoluble in water, hence, a milky solution resulted upon mixing them together before attempting the photopolymerization (Figure S1, left). Regardless, GZ3.163 did form covalently linked hydrogels in water (Figure S1) with similar reaction kinetics to the methanol samples. 


\subsection{Characteristics of the Hydrogel}

\subsubsection{Rheology}

Peptide hydrogel formation was confirmed by the tilt test (Scheme 1 hydrogel image after polymerization and Figure S1). Mechanical properties of the peptide-PEG gels in methanol and water were further analysed using rheology (Figure 1 and Figure S2).

\section{Methanol}
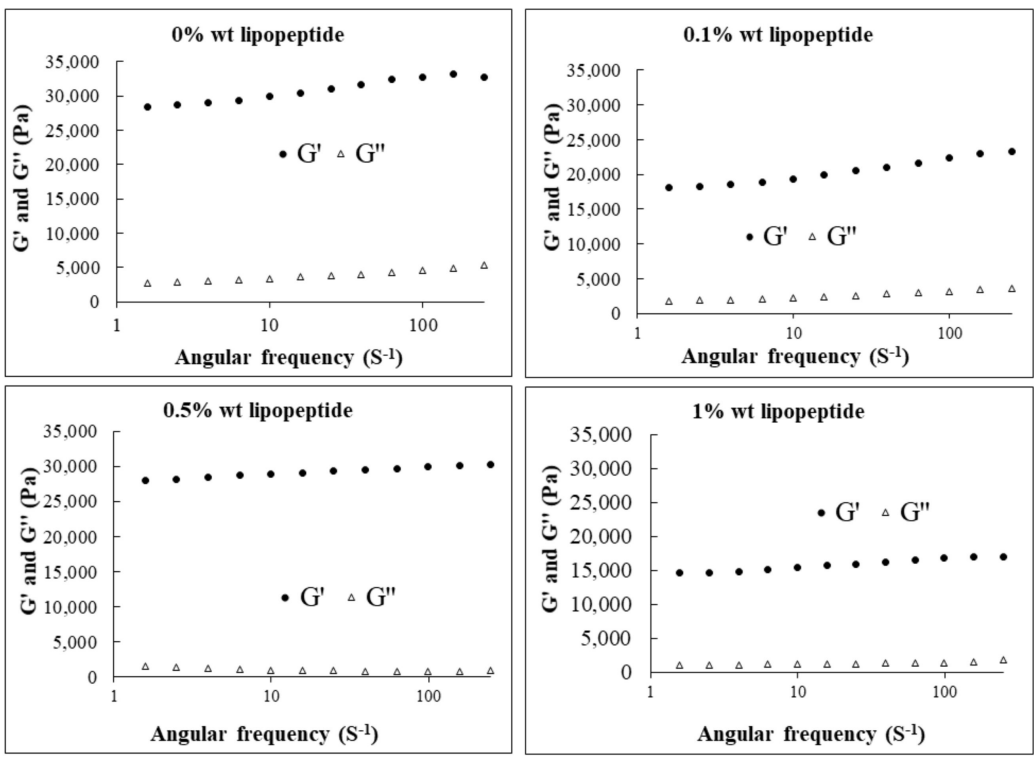

Water

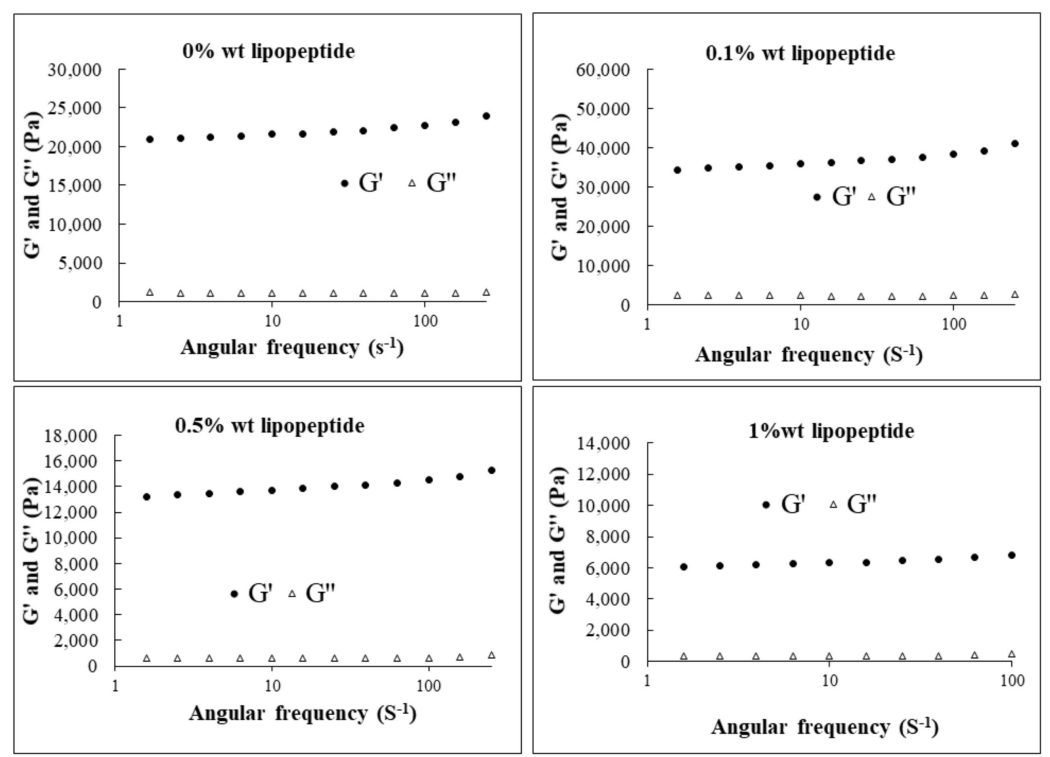

Figure 1. Storage $\left(G^{\prime}\right.$, closed circle) and loss $\left(G^{\prime \prime}\right.$, open triangle) moduli of the gel samples containing different concentrations of the lipopeptide prepared in methanol (top four graphs) and water (bottom four graphs).

As evident from Figure 1, the storage modulus of all the gels were significantly greater than the loss modulus, indicating the formation of an elastic gel network rather than a viscous liquid. The presence of the lipopeptide at varying concentrations did not affect gel formation in any way. However, the intensity of the storage and loss moduli between the methanol and water samples were 
different, possibly due to solubility issues of the PEG spacer and the crosslinker in water. Furthermore, all of the gel samples showed significant decrease in viscosity with increasing sheer rate (Figures S2 and S3) similar to gels reported by Lee et al. [27]. These gels exhibit sheer thinning ability as the physical linkage of the PEG matrix breaks upon applying shear stress. These are desirable characteristics for topical antibacterial applications, injectable gels and eye drops.

\subsubsection{Fourier Transform Infrared (FT-IR) Spectroscopy}

Successful conjugation of the lipopeptide onto the gel matrix was confirmed by FT-IR spectroscopy (Figure 2). With $10 \mathrm{wt} \%$ lipopeptide in methanol, a peak at $1668 \mathrm{~cm}^{-1}$ was observed. This peak corresponds to the amide I region and is mainly associated with carbonyl vibrations arising from the peptide molecules. The $10 \mathrm{wt} \%$ lipopeptide in water also observed a peak at $1641 \mathrm{~cm}^{-1}$ corresponding to amide I region (Figure S4). This characteristic peak was absent in the control gel sample devoid of the lipopeptide (0 wt\% lipopeptide.) At lower lipopeptide concentrations $(0.1-1 \mathrm{wt} \%$ ) the gels did not show the characteristic amide I and II bands possibly due to reduced lipopeptide concentration to yield any detectable signal [28].

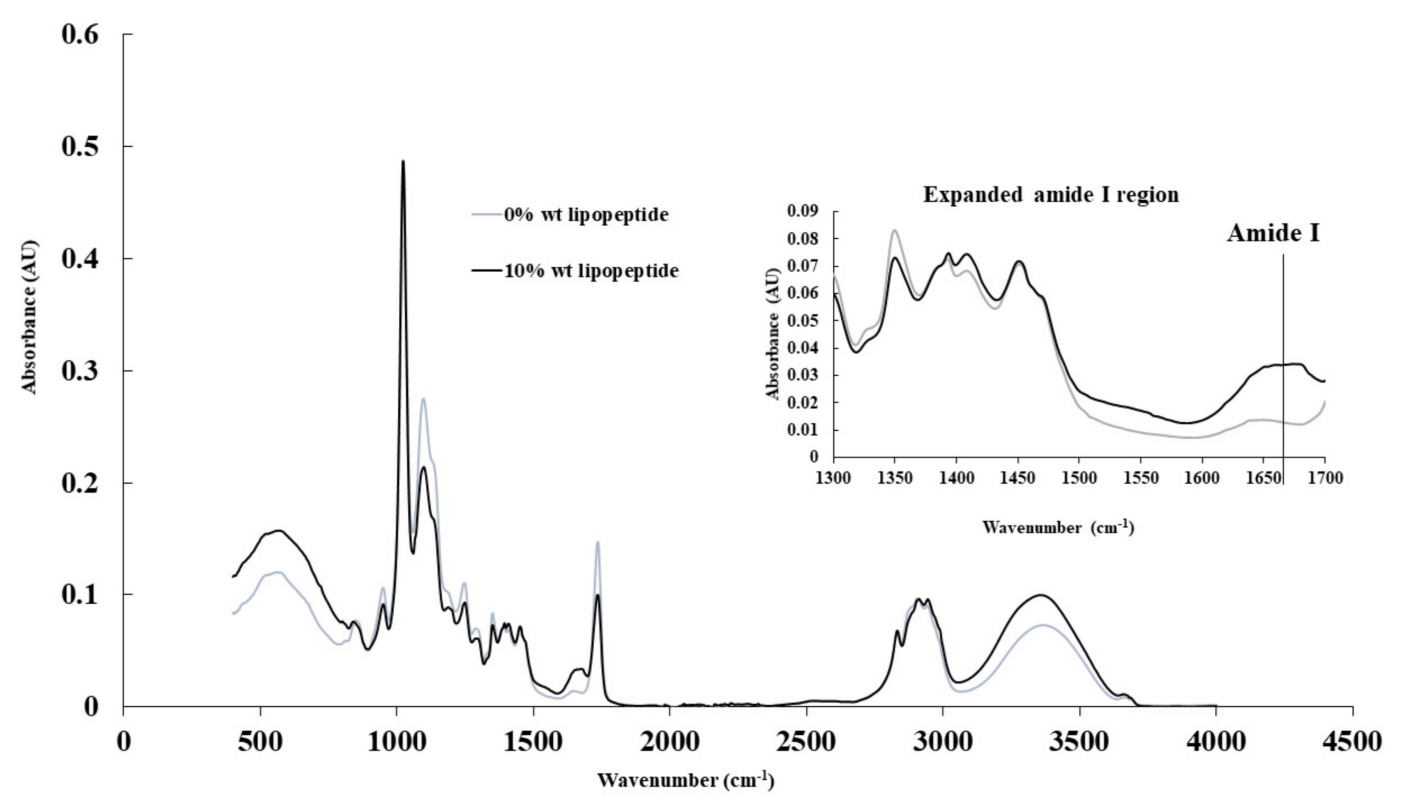

Figure 2. Full FT-IR spectrum of the PEG hydrogel prepared in methanol in the absence and presence of the lipopeptide.

\subsubsection{Scanning Electron Microscopy (SEM)}

The morphology of the lipopeptide gels were studied using SEM (Figure 3). As evident from Figure 3, the gels prepared in water and methanol exhibit different surface morphologies possibly due to the insolubility of PEG spacer and the tetrabranched cross linker in water. The hydrogels prepared in water (Figure 3, left) have a smoother surface compared to the gels prepared in methanol. However, they exhibit a criss-cross pattern throughout the surface as well as granular spherical particles embedded within the surface. It is possible that these granules are the insoluble starting materials while the criss-cross architecture could be the cross-linked polymer matrix. The methanol containing gels were highly coarse, which may be due to the extensive covalent crosslinking of the PEG materials. Unlike the gels prepared in water, those prepared in methanol were porous with pore sizes ranging from 0.2 to $1.9 \mu \mathrm{m}$. Such porous gels could have potential applications in wound dressing, as the porous structure in these gels is important for oxygen transport and absorption of exudates. The architecture of the gel remained the same for both 0 and $1 \mathrm{wt} \%$. 
Water

$0 \%$ wt
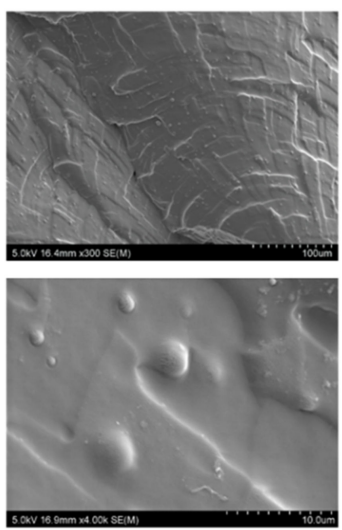

$1 \%$ wt
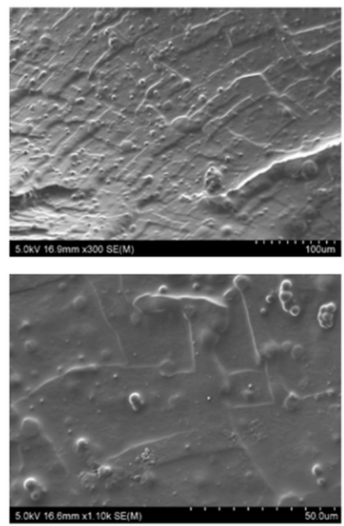

Methanol

$0 \%$ wt
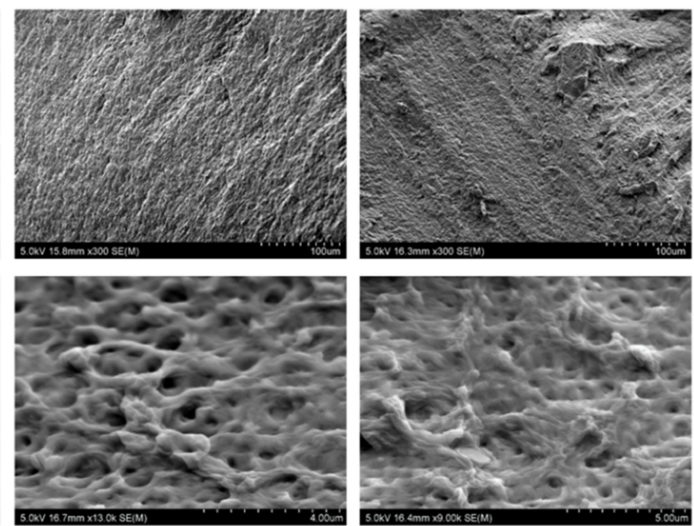

Figure 3. Representative SEM images of gels in the absence $(0 \mathrm{wt} \%)$ and presence $(1 \mathrm{wt} \%)$ of the lipopeptide. The top panel shows images taken at a magnification of $300 \times$ and the bottom panel at a magnification of 1000 to $4000 \times$ for the water samples and 9000 to $13,000 \times$ for the methanol samples.

\subsection{Antibacterial Analysis}

The antibacterial analysis of the lipopeptide containing gels (Figure 4) were performed against P. aeruginosa as a model Gram negative pathogen and S. aureus, as one of the common bacterial pathogens associated with skin infections.

\section{P. aeruginosa}

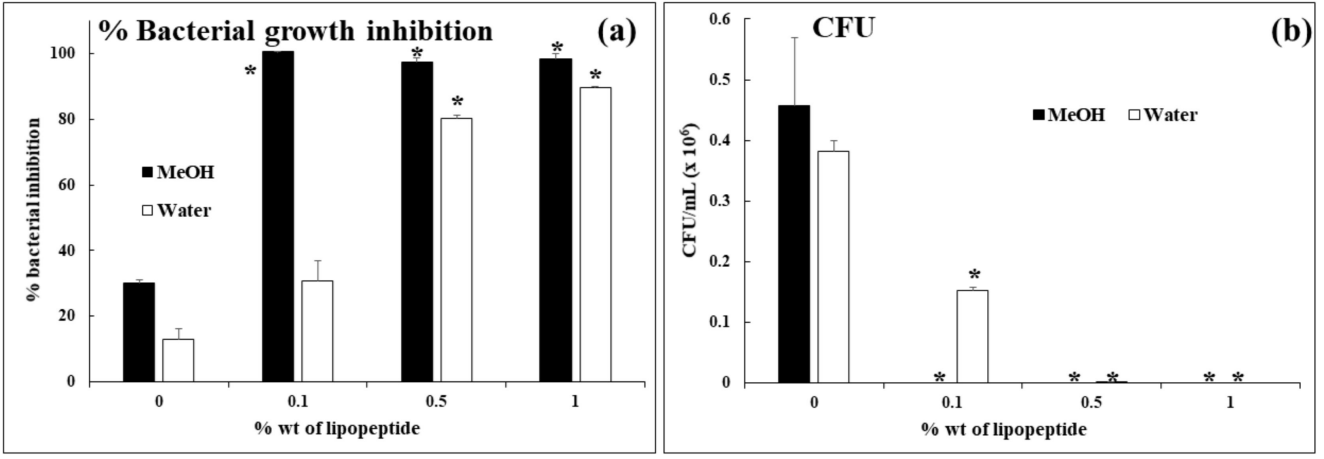

\section{S. aureus}

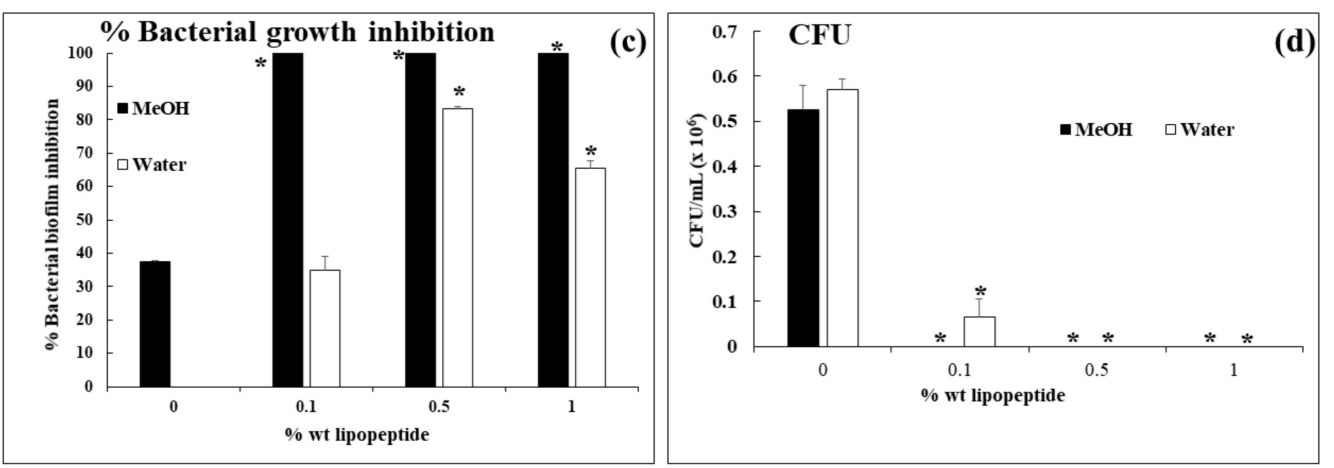

Figure 4. The antibacterial activity of lipopeptide containing gels against $P$. aeruginosa $(\mathbf{a}, \mathbf{b})$ and S. aureus $(\mathbf{c}, \mathbf{d})$. Results presented are averaged from three independent experiments done in triplicate. $(\mathbf{a}, \mathbf{c})$ represent percentage of bacterial reduction determined by the optical density of the solution. $(\mathbf{b}, \mathbf{d})$ are the recovered bacterial cells from the gel samples after sonication. ${ }^{*}$ Indicates $p<0.05$. 
The lowest weight percent of the peptides that showed antimicrobial activity in the hydrogels reported by Cleophas et al. was $10 \mathrm{wt} \%$ (relative to polymer content) against S. aureus, S. epidermidis and E. coli $[20,21]$. Our lipopeptide gels showed excellent antibacterial activity at a peptide content 100 times lower $(0.1 \mathrm{wt} \%)$ against P. aeruginosa and S. aureus. Lipopeptide gels prepared in methanol showed up to $97 \%$ bacterial growth inhibition (Figure $4 a, c$ ) against the two pathogens. In fact, no live bacteria were recovered from the samples (Figure $4 b, d$ ). These results indicate that the antibacterial activity of these lipopeptide gels are initiated upon bacterial contact (contact killing) with the gel sample. However, only 0.5 and 1 lipopeptide $w \mathrm{t} \%$ hydrogels in water showed potent antibacterial activity against $P$. aeruginosa and $S$. aureus. The discrepancy in the antibacterial activity between the gels prepared in methanol and water could be due to poor solubility of PEG matrix in water, as described earlier. The control PEG only gel ( $0 \mathrm{wt} \%$ of the lipopeptide) showed weak antibacterial activity against the two pathogens, possibly due to the antiadhesive properties of PEG. Weak antibacterial activity of PEG coated surfaces has been observed in our previous work [11].

\subsection{Anti-Biofilm Activity}

The gel samples at 0.5 to $1 \mathrm{wt} \%$ in methanol showed potent antibacterial activity (92-100\% growth inhibition) against the cells released from both P. aeruginosa and S. aureus biofilms (Figure S5). The lipopeptide hydrogels at 0.5 and $1 \mathrm{wt} \%$ prepared in water showed moderate antibacterial activity (56-60\% inhibition) against $P$. aeruginosa cells released from the mature biofilm (Figure S5a). However, the antibacterial activity of lipopeptide hydrogels against cells released from the $S$. aureus biofilm (Figure S5b) was weak (23\% inhibition at $1 \mathrm{wt} \%$ ).

The ability of the lipopeptide gels to disrupt mature biofilms (7 days old) of $P$. aeruginosa and S. aureus was studied using a crystal violet staining assay. Crystal violet is known to bind to the exopolysaccharide matrix (EPS) in the biofilm. The stained biofilm can be solubilised upon addition of ethanol for a semi-quantitative estimation of the attached biofilm biomass. As evident from Figure 5a,c, hydrogel samples prepared in water did not completely eradicate ( $23 \%$ biomass reduction at $1 \mathrm{wt} \%$ ) the mature biofilms of $P$. aeruginosa (Figure $5 \mathrm{a}$ ). The $1 \mathrm{wt} \%$ lipopeptide in water eradicated up to $59 \%$ of the mature biofilms of $S$. aureus (Figure $5 \mathrm{c}$ ). The 0.5 and $1 \mathrm{wt} \%$ lipopeptide-gels in methanol exhibit 70 to $86 \%$ reduction in biomass (Figure $5 \mathrm{a}, \mathrm{c}$ ) which is a promising result when it comes to eradicating mature biofilms of the two pathogens. Unlike the gel samples prepared in water, no mature biofilm cells were recovered from $0.5 \mathrm{wt} \%$ and $1 \mathrm{wt} \%$ methanol gel samples (Figure 5b,d).

\section{P. aeruginosa}

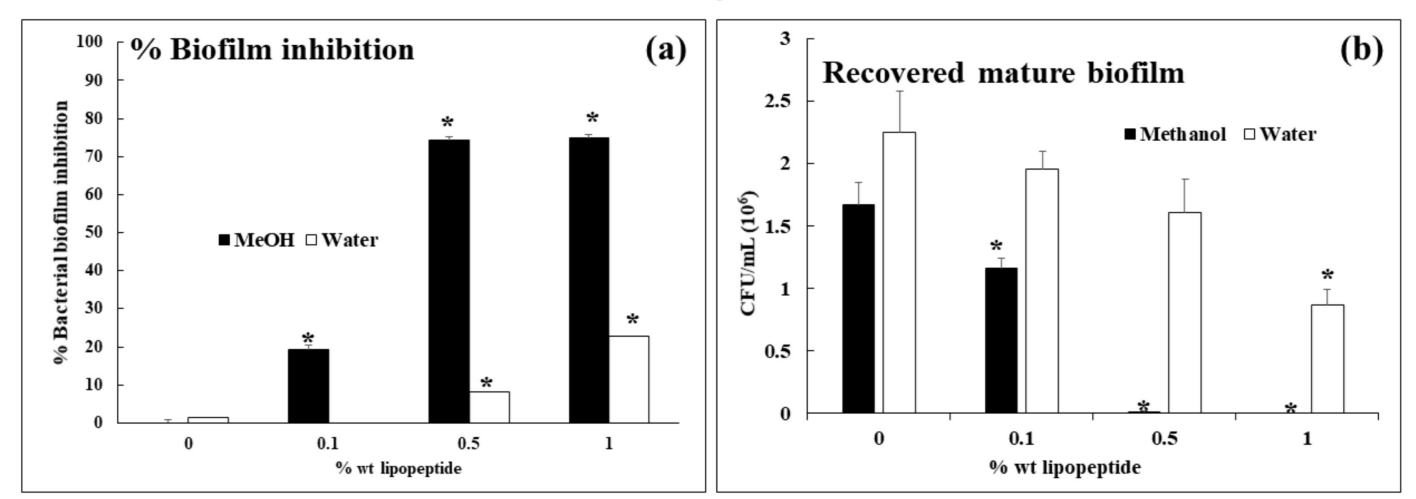

Figure 5. Cont. 


\section{S. aureus}
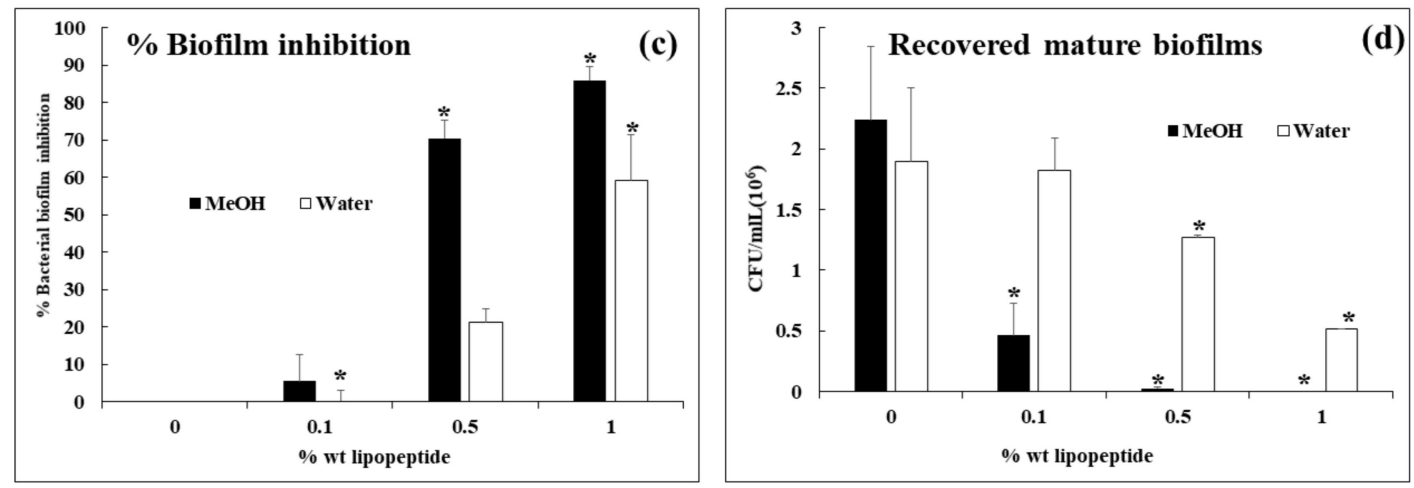

Figure 5. The effect of lipopeptide gels on mature (seven days old) biofilms P. aeruginosa and S. aureus. $(\mathbf{a}, \mathbf{c})$ represent the percentage of bacterial biofilm mass reduction determined by the optical density of the solubilised crystal violet recovered from the stained biofilm of P. aeruginosa and S. aureus respectively. $(\mathbf{b}, \mathbf{d})$ are the recovered mature biofilm cells of P. aeruginosa and S. aureus respectively after sonicating the gel samples. Results presented are averaged from two independent experiments done in triplicate * Indicates $p<0.05$.

These results indicate that the lipopeptide gels prepared in methanol have promising antibacterial and anti-biofilm activity against the two bacteria even though eradication of mature biofilms required slightly higher lipopeptide content $(\leq 0.5 \mathrm{wt} \%)$ than required for eradicating the planktonic $(\leq 0.1 \mathrm{wt} \%)$ cells. This result is not surprising as higher bacterial cell density is observed in mature biofilms. The bacterial cells within the biofilm are surrounded by EPS that accounts for 50 to $90 \%$ of the biomass in the biofilm. The EPS acts as a physical barrier against hostile conditions such as UV exposure, acid stress, and metal toxicity, thereby acting as the first line of defence against antibiotics [1,29]. Because of being covalently linked to the PEG matrix, the lipopeptide molecules are unlikely to leach out from the gel matrix and diffuse through the EPS, which would explain the need for a higher peptide content for the eradication of the mature biofilms. Nevertheless, these lipopeptide gels have the ability to prevent colonisation of biofilms onto new sites due to their contact kill mechanism of action.

\subsection{Haemolysis of Mouse Blood Cells}

To qualify for clinical use, toxicity below a particular threshold is essential in addition to antibacterial potency. Previously we have shown that several peptides from the battacin lipopeptide library have negligible haemolytic activity against mouse blood cells $[9,11,13]$. It was still important to determine the haemolytic activity of the lipopeptide gels against mouse blood cells to rule out that this formulation is not haemolytic (Figure 6) as our self-assembling gels were haemolytic. 


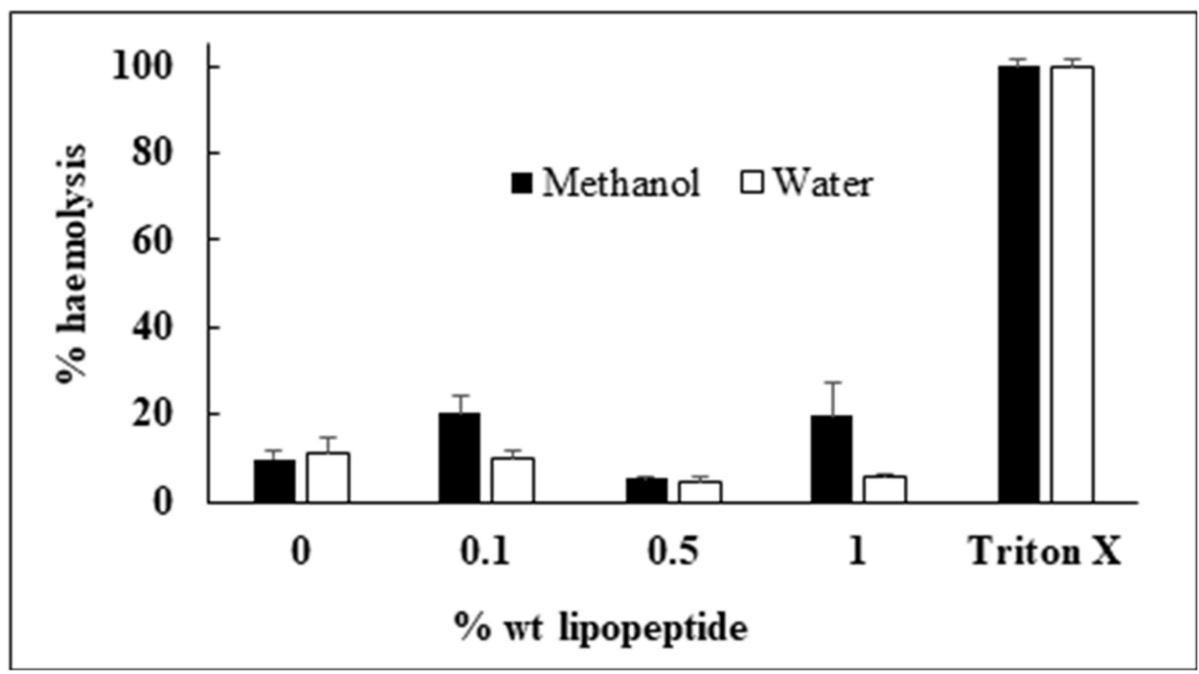

Figure 6. Percentage haemolysis of mouse blood cells by the gels prepared in methanol and water.

Both the gels prepared in methanol and water in the absence of the lipopeptide $(0 \mathrm{wt} \%)$ showed negligible (9-11\%) haemolysis against mouse blood cells. In the presence of the lipopeptide, a slight increase in haemolysis (5-20\%) was observed but was within the expected range $(\geq 20 \%)$ for peptide hydrogels reported in the literature [30-33].

\subsection{In Vitro Cytotoxicity Against Human Dermal Fibroblast Cells}

Our ultrashort battacin based lipopeptides exhibited a $50 \%$ cell viability at $\geq 125 \mu \mathrm{M}$ between a 24 and $72 \mathrm{~h}$ time period [10]. The cytotoxic activity of synthetic battacin lipopeptide analogue GZ3.163 has not been previously investigated. The cytotoxicity of GZ3.163 was evaluated following a MTT cell viability assay of human dermal fibroblasts (Figure S6). As evident from Figure S6, up to 50\% cell viability was observed for GZ3.163 at $\geq 125 \mu \mathrm{M}$ between a 24 to $72 \mathrm{~h}$ time period. The cytotoxicity range observed is same as the ultrashort battacin lipopeptides [10] and similar to what has been reported previously for the natural product battacin (128 $\mu \mathrm{M}$ against the HEK 293 human kidney cell lines) [8].

The results from the cell viability assay on the lipopeptide gels are shown in Figure 7. In general, cell viability was found to increase with increasing concentration of the peptides in the gels. It was observed that increased contact time had a detrimental effect on cell viability, which changed from 109 to $140 \%$ at $24 \mathrm{~h}$ to 75 to $86 \%$ in $72 \mathrm{~h}$ (Figure 7 ). The fact that $>75 \%$ cell viability was retained after $72 \mathrm{~h}$ of contact with the lipopeptide gels prepared in both methanol and water is very encouraging and prove the non-cytotoxic nature of these lipopeptide gels against the human dermal fibroblasts, which is within the expected range $(60-100 \%)$ for peptide hydrogels reported in the literature $[14,22,27,30]$. 


\section{Methanol}
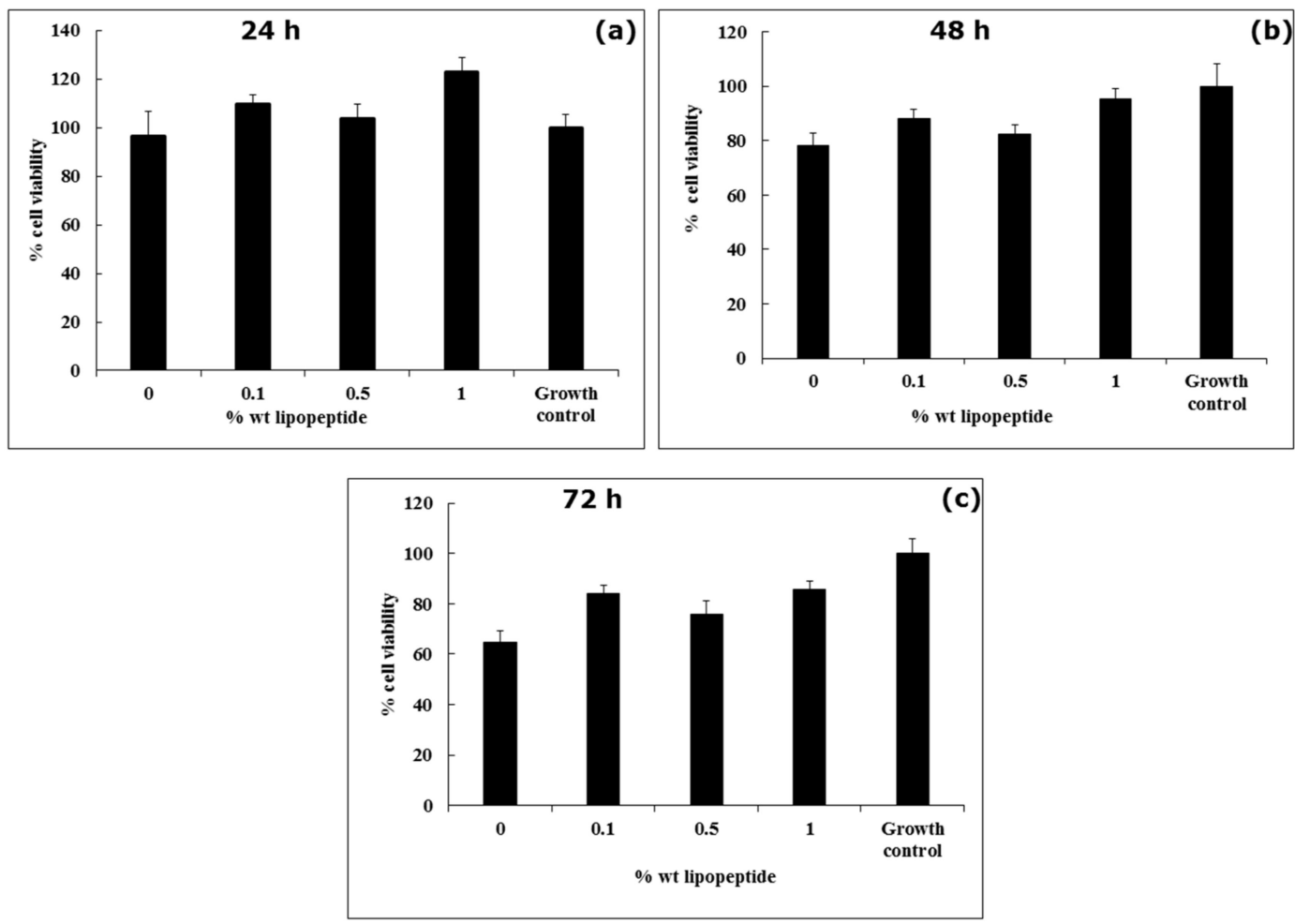

Water
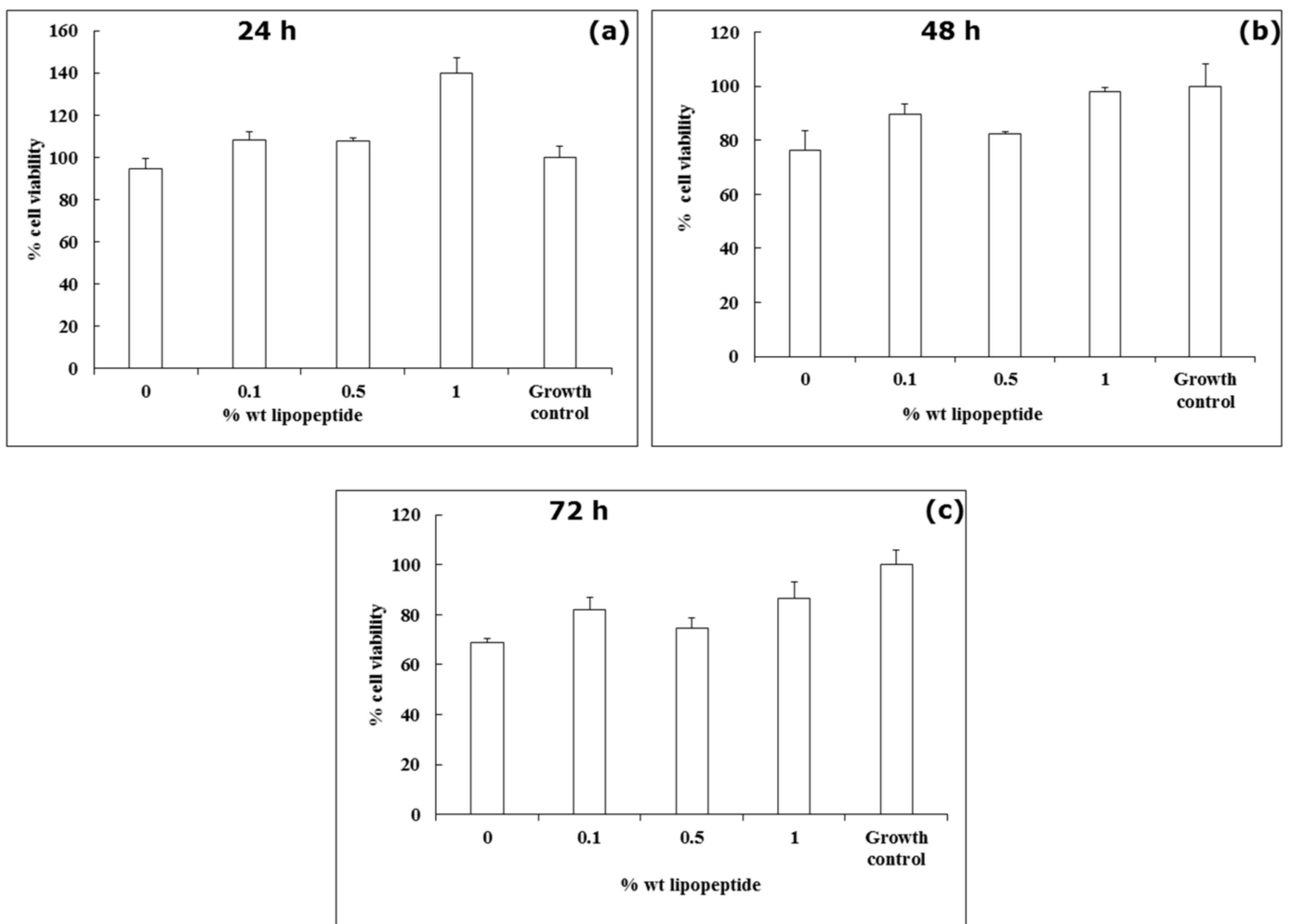

Figure 7. MTT- cell viability assay of human dermal fibroblasts treated with different content (wt $\%$ ) of lipopeptide gels at different time intervals (a) $24 \mathrm{~h},(\mathbf{b}) 48 \mathrm{~h}$ and (c) $72 \mathrm{~h}$. 


\section{Conclusions}

Thiol-ene click chemistry was used to convert a linear lipopeptide from the battacin family into an antimicrobial gel by covalent conjugation to PEG matrix. These lipopetide gels were characterised by rheology and successful immobilisation of the peptide component in the gel network was confirmed using FTIR, which showed a dominant peak at $1668 \mathrm{~cm}^{-1}$ attributed to the amide I band of the peptide molecules. The gel containing as low as $0.1 \mathrm{wt} \%$ of the lipopeptide was capable of completely inhibiting the growth of P. aeruginosa and S. aureus, which is a significant improvement to previous literature reports where bacterial growth inhibition could not be achieved below $10 \mathrm{wt} \%$ of the peptide component. None of the previous reports have investigated biofilm inhibition using antimicrobial peptide gels or have presented any toxicity data. Our antibacterial and anti-biofilm analyses have shown that at a minimum peptide content of $0.5 \mathrm{wt} \%$. the gels prepared in methanol, successfully inhibit both planktonic and mature biofilms of P. aeruginosa and S. aureus. Similar to our previously reported lipopeptides from this family, these synthetic peptide gels were not haemolytic against mouse blood cells. The control gels prepared in methanol showed negligible haemolytic activity and cytotoxicity against human dermal fibroblasts, indicating that the chemistry used here would be amenable for developing drug formulations that can be directly used in patients to treat infections. Additionally, incorporation of the peptide into the PEG gel matrix lead to an increase in cell viability, which implies that the peptide gel provides favourable conditions for cell harvesting. In summary, results from the current investigations prove that the battacin lipopeptide gels are ideal candidates that hold promise for development as novel topical antibiotics because of their antibacterial and antibiofilm activities and promising safety profile.

\section{Materials and Methods}

\subsection{Chemicals and Reagents}

All solvents were of analytical grade and were used without further purification. Pentaerythritol tetrakis(3-mercaptopropionate) (PTMP), poly(ethylene glycol) diacrylate (PEGDA) (Mn 700), 2,2-dimethoxy-2-phenylacetophenone (DMPA), crystal violet, and 3-(4,5-dimethylthiazol-2-yl)-2,5-dipheynyltetrazolium bromide (MTT) were purchased from Sigma Aldrich (St. Louis, MO, USA). Human dermal fibroblasts (Cell line HDFa, catalogue number: C0135C) and low serum growth supplement (LSGS, Catalog number: S00310) were purchased from Life Technologies NZ (Auckland, New Zealand). The N-terminal cys containing lipopeptide (GZ3.163) was synthesised following standard solid phase peptide synthesis protocols using Fmoc chemistry. The detailed experimental procedure for the synthesis, purification, and characterisation of this peptide has been reported in our previous publications $[9,11,13]$.

\subsection{Gel Formation}

PTMP (2 g, $4.1 \mathrm{mmol})$, PEGDA (7 g, $10 \mathrm{mmol})$ and catalytic amount of DMPA as the photoinitiator $(0.1 \mathrm{wt} \%, \sim 10 \mathrm{mg})$ were mixed together. The lipopeptide at $0.1 \mathrm{wt} \%(0.4 \mathrm{mg}, 0.26 \mu \mathrm{mol}), 0.5 \mathrm{wt} \%(2 \mathrm{mg}$, $1.3 \mu \mathrm{mol}), 1 \mathrm{wt} \%(4 \mathrm{mg}, 2.6 \mu \mathrm{mol})$, and $10 \mathrm{wt} \%(40 \mathrm{mg}, 26 \mu \mathrm{mol})$, relative to polymer content was dissolved in either methanol $(1.33 \mathrm{~mL})$ or water $(1.33 \mathrm{~mL})$. The polymer mixture $(0.33 \mathrm{~mL}, 389 \mathrm{mg})$ was added dropwise to the peptide solution. The polymer mixture was completely soluble in methanol but was insoluble in water. The gelation was initiated with a UV lamp at $365 \mathrm{~nm}$ (intensity ca. $4.6 \mathrm{mw}$ $\mathrm{cm}^{-2}$ or $25 \mathrm{mWcm}^{-2}$ for $15 \mathrm{~min}$ ) for 1 to $10 \mathrm{~min}$. Successful gelation was initially validated by inverting the vial (Figure 1 and Figure S1) [20,21].

\subsection{Rheology}

Oscillatory rheometer (MCR 302, Anton Paar Austria) with a stainless-steel plate (25 mm diameter) at $25 \pm 1{ }^{\circ} \mathrm{C}$ was used to further characterise these gels. A gap height of $0.2 \mathrm{~mm}$ was maintained between the plates before each measurement. A dynamic sweep was applied at an angular frequency 
of $6 \mathrm{rad} / \mathrm{s}$. Finally, a frequency sweep of 1 to $100 \mathrm{rad} / \mathrm{s}$ with $1 \%$ strain amplitude $(\gamma)$ was used to record the viscoelastic behaviour. The storage modulus $\left(\mathrm{G}^{\prime}\right)$ and loss modulus $\left(\mathrm{G}^{\prime \prime}\right)$ were calculated as a function of angular frequency at every point. For shear-thinning experiment, hydrogels were examined as a function of shear rate from 0.1 to $1 \mathrm{~s}^{-1}[18,27]$

\subsection{Fourier Transform Infrared (FT-IR) Spectroscopy}

FT-IR spectra were recorded using a PerkinElmer Spectrum Two FT-IR spectrometer (PerkinElmer, Buckinghamshire, UK) fitted with an ATR diamond crystal attachment, operated in single bounce mode. The gel samples were scanned from 400 to $4000 \mathrm{~cm}^{-1}$ and at every $2 \mathrm{~cm}^{-1}$ increments, an average of 36 scans were recorded. The spectrum from methanol was subtracted as the background [10,34].

\subsection{Scanning Electron Microscopy}

The gel samples were thoroughly freeze dried to obtain the dry gel. The dried samples were placed in a carbon tape onto an aluminum stud and sputter coated with gold, for $20 \mathrm{~s}$ at $25 \mathrm{~mA}$ before viewing under high vacuum using Hitachi Su-70, SEM microscope (Hitachi, Tokyo, Japan), at $5 \mathrm{kV}$ at the Faculty of Science, Auckland University of Technology [35].

\subsection{Antibacterial Analysis}

S. aureus and P. aeruginosa ATCC 27853 were obtained from the microbial culture collection of the School of Biological Sciences or the Faculty of Medical and Health Sciences, at the University of Auckland. These two strains produce biofilms, as reported on our previous study [9] and by others [36]. For the antibacterial assay, a single colony of bacteria was transferred to and grown overnight in Muller Hinton broth (MHB) broth. The optical density of the overnight culture was adjusted to 0.5 Mcfarland standard and was further diluted 100 times to obtain a final bacterial concentration of $10^{6} \mathrm{CFU} / \mathrm{mL}$. The pre prepared gel samples ( $25 \mathrm{mg} \pm 3 \mathrm{mg}$ ) in methanol and water at $0 \%, 0.1 \%$, $0.5 \%$ and $1 \%$ lipopeptide weight relative to polymer content were placed in polypropylene coated 96 well plates (greiner-Bio-one, MediRay). The diluted bacterial solution $(100 \mu \mathrm{L})$ was added to each well. For comparative purposes, the plates also had both growth and sterility controls (negative control) included, both of which did not contain the gels. The positive control was the GZ3.163 lipopetide $(1 \mathrm{mM})$ which has previously shown activity against $S$. aureus and $P$. aeruginosa [11]. The plates were incubated overnight at $37^{\circ} \mathrm{C}$ without any agitation. The gels were removed from the 96 well plates and washed thrice with sterile saline solution $(0.9 \% \mathrm{NaCl}, 200 \mu \mathrm{L})$ to remove any non-adhered bacteria. The optical density of the bacterial supernatant in the 96 well plate was measured at $600 \mathrm{~nm}$ using an EnSpire Multimode plate reader and the \% of bacterial inhibition was calculated using the following equation

$$
\% \text { bacterial growth inhibition }=\left(1-\left(\text { Aexp }-A_{M H B}\right) /\left(A_{G C}-A_{M H B}\right) \times 100\right) \text {, }
$$

where, Aexp is the absorbance of the supernatant from the wells containing the gel samples, $\mathrm{A}_{\mathrm{MHB}}$ is the absorbance of the MHB broth (sterility control) and $\mathrm{A}_{\mathrm{GC}}$ is the absorbance of the bacterial growth control in the absence of gel samples.

The washed gels were transferred to fresh saline $(0.5 \mathrm{~mL})$ and sonicated for $5 \mathrm{~min}$ at $30 \mathrm{~W}$ to release the adhered bacteria on the gel surfaces. The retrieved bacteria were further diluted 10,000 times with saline and $100 \mu \mathrm{L}$ of the diluted bacterial culture was plated onto MHB agar plates and incubated at $37^{\circ} \mathrm{C}$ overnight. The following day, the number of colonies on each plate was counted to assess the antibacterial potency of the gels. These experiments were done in triplicate and repeated three times on independent days [11,18,20,21]. 


\subsection{Anti-Biofilm Analysis}

P. aeruginosa and S. aureus cultures grown overnight were diluted to a final bacterial concentration of $10^{6} \mathrm{CFU} / \mathrm{mL}$ and $100 \mu \mathrm{L}$ of the diluted bacterial culture was inoculated into a tissue culture treated flat bottom polystyrene 96 well plate (Corning, Sigma Aldrich) and mature biofilms were allowed to grow for seven days at $37^{\circ} \mathrm{C}$ without agitation. During each day, the bacterial supernatant was carefully removed without disturbing biofilm cells at the bottom of the wells, the wells carefully were washed twice with saline $(200 \mu \mathrm{L})$ to remove any planktonic cells and were replaced with fresh MHB medium. On the seventh day, gel samples were added to the mature biofilms and the plate incubated overnight at $37^{\circ} \mathrm{C}$. The assay included growth and the sterility controls. The gels were carefully removed without disrupting the biofilms, and were washed thrice with saline to remove any loosely adhered biofilm cells. The CFU assay to assess the potency of the gels on the biofilm cells was conducted following the same methodology described in the antibacterial section. The bacterial supernatant from each well was carefully transferred to the wells of a fresh 96 well plate and the optical density and the percentage of bacterial inhibition determined using the methodology described under antibacterial analysis.

The ability of the gel samples to disrupt mature biofilms was determined using a crystal violet staining assay. After removing the supernatant, the biofilms were gently washed thrice with saline $(100 \mu \mathrm{L})$ to remove any planktonic cells. The biofilms were then fixed by adding methanol $(100 \mu \mathrm{L})$ for $15 \mathrm{~min}$, after removing which, the biofilms were washed once with saline. Crystal violet (1\% w/v, $100 \mu \mathrm{L}$ ) was added to each well and the plate incubated for $10 \mathrm{~min}$ at room temperature. After removing any excess stain, the wells were washed thrice with saline. The stained biofilm was solubilised by adding $96 \%$ ethanol $(100 \mu \mathrm{L})$ for $5 \mathrm{~min}$. The solubilised dye from each well was transferred to a fresh plate and optical density at $560 \mathrm{~nm}$ measured for a semi quantitative estimation of the bacterial biofilm mass. The percentage reduction in bacterial biofilms was calculated using the formula described under the antibacterial analysis. The experiment was performed in triplicates and was repeated two times on independent days. $[9,27,37]$

\subsection{Haemolytic Assay}

The procedure reported in our previous publications $[9,11,13]$ was followed for the haemolytic assay, with minor modifications as described below. Freshly collected mouse blood cells were centrifuged at $1000 \mathrm{~g}$ for $5 \mathrm{~min}$ to remove the buffy coat. The blood cells were washed three times in Tris buffer (10 mM Tris, $150 \mathrm{mM} \mathrm{NaCl}, \mathrm{pH} 7.4)$ and re-suspended in 2\% (v/v) Tris buffer. The lipopeptide gels (peptide concentration ranging from 0.21 to $2.1 \mathrm{mM})$ pre prepared in methanol and water ( $25 \mathrm{mg}$ $\pm 2 \mathrm{mg}$ ) were placed into the wells of a 96 well plate and the re-suspended blood cells $(200 \mu \mathrm{L})$ were added to the gel samples. The Tris buffer solution and $0.1 \%$ Triton $\mathrm{X}-100$ were used as the negative and positive controls respectively. The plates were incubated for $1 \mathrm{~h}$, at $37^{\circ} \mathrm{C}$ without agitation. The gel samples were removed and the plates were centrifuged at $3500 \mathrm{~g}$ for $10 \mathrm{~min}$. The supernatant $(100 \mu \mathrm{L})$ from each well was carefully transferred into a new plate and the absorbance at $540 \mathrm{~nm}$ measured. The experiment was done in triplicate and repeated twice on independent days. Percentage haemolysis of lipopeptide gels was determined using the following equation,

$$
\% \text { haemolysis }=(\text { Aexp }- \text { ATris }) /(\text { A100 } \%-\text { ATris }) \times 100,
$$

where, $A_{\text {exp }}$ is the absorbance of the gel samples at $540 \mathrm{~nm}, A_{\text {Tris }}$ is the absorbance of negative control and $\mathrm{A}_{100 \%}$ is the absorbance of the $0.1 \%$ Triton $\mathrm{X}-100$ solution (positive control) $[9,11,13]$.

\subsection{Cytotoxicity Assay}

The cytoxicity assay protocol previously reported by us was followed with minor modifications. Human dermal fibroblast (cell line HDFa), grown in medium 106 supplemented with low serum growth supplement, were seeded $(100 \mu \mathrm{L})$ into tissue culture treated 96 well plates at a cell density 
of 50,000 cells $/ \mathrm{mL}$ and incubated overnight at $37{ }^{\circ} \mathrm{C}$ with $5 \% \mathrm{CO}_{2}$. After overnight incubation, the media was carefully removed, and the lipopeptide gel samples were placed into the respective wells. Fresh growth media was added to each well and the plates were incubated for 24,48 , and $72 \mathrm{~h}$ time intervals. At each time point, the gel samples and the media were carefully removed exposing the treated cells. The cell viability, reported as percentage of the dermal fibroblast cells treated with the lipopeptide gels compared to the control, was verified by MTT assay (Sigma, Auckland, NZ), carried out according to the manufacturer's instructions. The Viable cell amount (based on the intensity of the MTT-formazan complex) was determined by measuring absorbance at $540 \mathrm{~nm}$ using a multiplate reader (UV-visible FLUOStar Omega Multidetection Microplate Reader, AlphaTech NZ Ltd., Auckland, New Zealand). The experiment was carried out in triplicates and repeated two times on independent days [10].

Supplementary Materials: The following are available online. Figure S1: Photograph of Peptide-PEG hydrogel, Figure S2: Sheer thinning experiment of methanol gels, Figure S3: Sheer thinning experiment of hydrogels, Figure S4: FT-IR spectrum of hydrogels prepared in water, Figure S5: biofilm assay graph, Figure S6: MTT viability assay of the lipopeptide.

Author Contributions: Conceptualization, G.H.D.Z. and V.S.; data curation, J.L., Y.H. and V.S.; investigation, G.H.D.Z. and V.S.; methodology, K.W.; resources, J.L., Y.H. and V.S.; supervision, V.S.; writing-original draft, G.H.D.Z.; writing - review and editing, V.S.; funding acquisition, V.S. All authors have read and agreed to the published version of the manuscript.

Funding: This research was support through funding from The University of Auckland, FRDF grant 3712381.

Acknowledgments: We thank Yuan Tao from Auckland University of Technology for technical assistance with acquiring SEM images.

Conflicts of Interest: The authors declare no conflict of interest.

\section{References}

1. Hall-Stoodley, L.; Costerton, J.W.; Stoodley, P. Bacterial biofilms: From the Natural environment to infectious diseases. Nat. Rev. Genet. 2004, 2, 95-108. [CrossRef] [PubMed]

2. Centers for Disease Control and Prevention. Antibiotic Resistance Threats in the United States, 2013; Centers for Disease Control and Prevention: Atlanta, GA, USA, 2013.

3. Hancock, R.E.; Lehrer, R. Cationic peptides: A new source of antibiotics. Trends Biotechnol. 1998, 16, 82-88. [CrossRef]

4. Boman, H.G. Peptide Antibiotics and Their Role in Innate Immunity. Annu. Rev. Immunol. 1995, 13, 61-92. [CrossRef] [PubMed]

5. Hancock, R.E.; Sahl, H.-G. Antimicrobial and host-defense peptides as new anti-infective therapeutic strategies. Nat. Biotechnol. 2006, 24, 1551-1557. [CrossRef] [PubMed]

6. Falagas, M.E.; Kasiakou, S.K.; Saravolatz, L.D. Colistin: The Revival of Polymyxins for the Management of Multidrug-Resistant Gram-Negative Bacterial Infections. Clin. Infect. Dis. 2005, 40, 1333-1341. [CrossRef]

7. Steenbergen, J.N.; Alder, J.; Thorne, G.M.; Tally, F.P. Daptomycin: A lipopeptide antibiotic for the treatment of serious Gram-positive infections. J. Antimicrob. Chemother. 2005, 55, 283-288. [CrossRef]

8. Qian, C.-D.; Wu, X.-C.; Teng, Y.; Zhao, W.-P.; Li, O.; Fang, S.-G.; Huang, Z.; Gao, H. Battacin (Octapeptin B5), a New Cyclic Lipopeptide Antibiotic from Paenibacillus tianmuensis Active against Multidrug-Resistant Gram-Negative Bacteria. Antimicrob. Agents Chemother. 2011, 56, 1458-1465. [CrossRef]

9. De Zoysa, G.H.; Cameron, A.J.; Hegde, V.V.; Raghothama, S.; Sarojini, V. Antimicrobial Peptides with Potential for Biofilm Eradication: Synthesis and Structure Activity Relationship Studies of Battacin Peptides. J. Med. Chem. 2015, 58, 625-639. [CrossRef]

10. Glossop, H.D.; De Zoysa, G.H.; Hemar, Y.; Cardoso, P.; Wang, K.; Lu, J.; Valéry, C.; Sarojini, V. Battacin-Inspired Ultrashort Peptides: Nanostructure Analysis and Antimicrobial Activity. Biomacromolecules 2019, 20 , 2515-2529. [CrossRef]

11. De Zoysa, G.H.; Sarojini, V. Feasibility Study Exploring the Potential of Novel Battacin Lipopeptides as Antimicrobial Coatings. ACS Appl. Mater. Interfaces 2017, 9, 1373-1383. [CrossRef] 
12. Glossop, H.D.; Pearl, E.; De Zoysa, G.H.; Sarojini, V. Linear Analogues of the Lipopeptide Battacin with Potent In Vitro Activity Against S. aureus. Adv. Protein Chem. Struct. Biol. 2018, 112, 385-394. [CrossRef] [PubMed]

13. De Zoysa, G.H.; Glossop, H.D.; Sarojini, V. Unexplored antifungal activity of linear battacin lipopeptides against planktonic and mature biofilms of C. albicans. Eur. J. Med. Chem. 2018, 146, 344-353. [CrossRef] [PubMed]

14. Wang, L.; Li, X.; Sun, T.; Tsou, Y.-H.; Chen, H.; Xueqing, Z. Dual-Functional Dextran-PEG Hydrogel as an Antimicrobial Biomedical Material. Macromol. Biosci. 2017, 18, 1700325. [CrossRef] [PubMed]

15. Cui, H.; Webber, M.J.; Stupp, S.I. Self-assembly of peptide amphiphiles: From molecules to nanostructures to biomaterials. Pept. Sci. Orig. Res. Biomol. 2010, 94, 1-18. [CrossRef] [PubMed]

16. Tomasini, C.; Castellucci, N. Peptides and peptidomimetics that behave as low molecular weight gelators. Chem. Soc. Rev. 2013, 42, 156-172. [CrossRef]

17. Dasgupta, A.; Mondal, J.H.; Das, D. Peptide hydrogels. RSC Adv. 2013, 3, 9117-9149. [CrossRef]

18. Hoque, J.; Haldar, J. Direct Synthesis of Dextran-Based Antibacterial Hydrogels for Extended Release of Biocides and Eradication of Topical Biofilms. ACS Appl. Mater. Interfaces 2017, 9, 15975-15985. [CrossRef]

19. Song, A.; Rane, A.A.; Christman, K.L. Antibacterial and cell-adhesive polypeptide and poly(ethylene glycol) hydrogel as a potential scaffold for wound healing. Acta Biomater. 2012, 8, 41-50. [CrossRef]

20. Cleophas, R.T.C.; Sjollema, J.; Busscher, H.J.; Kruijtzer, J.A.W.; Liskamp, R.M.J. Characterization and Activity of an Immobilized Antimicrobial Peptide Containing Bactericidal PEG-Hydrogel. Biomacromolecules 2014, 15, 3390-3395. [CrossRef]

21. Cleophas, R.T.C.; Riool, M.; Van Ufford, H.; Linda, C.Q.; Zaat, S.A.J.; Kruijtzer, J.A.W.; Liskamp, R.M.J. Convenient Preparation of Bactericidal Hydrogels by Covalent Attachment of Stabilized Antimicrobial Peptides Using Thiol-ene Click Chemistry. ACS Macro Lett. 2014, 3, 477-480. [CrossRef]

22. Gharibi, R.; Yeganeh, H.; Abdali, Z. Preparation of antimicrobial wound dressings via thiol-ene photopolymerization reaction. J. Mater. Sci. 2017, 53, 1581-1595. [CrossRef]

23. Zhou, C.; Truong, V.X.; Qu, Y.; Lithgow, T.; Fu, G.; Forsythe, J.S. Antibacterial poly(ethylene glycol) hydrogels from combined epoxy-amine and thiol-ene click reaction. J. Polym. Sci. Part A Polym. Chem. 2015, 54, 656-667. [CrossRef]

24. Tucker-Schwartz, A.K.; Farrell, R.A.; Garrell, R.L. Thiol-ene Click Reaction as a General Route to Functional Trialkoxysilanes for Surface Coating Applications. J. Am. Chem. Soc. 2011, 133, 11026-11029. [CrossRef] [PubMed]

25. Aimetti, A.A.; Machen, A.J.; Anseth, K.S. Poly(ethylene glycol) hydrogels formed by thiol-ene photopolymerization for enzyme-responsive protein delivery. Biomaterials 2009, 30, 6048-6054. [CrossRef] [PubMed]

26. Burujeny, S.B.; Atai, M.; Yeganeh, H. Assessments of antibacterial and physico-mechanical properties for dental materials with chemically anchored quaternary ammonium moieties: Thiol-ene-methacrylate vs. conventional methacrylate system. Dent. Mater. 2015, 31, 244-261. [CrossRef]

27. Lee, A.L.; Ng, V.W.; Wang, W.; Hedrick, J.L.; Yang, Y.Y. Block copolymer mixtures as antimicrobial hydrogels for biofilm eradication. Biomaterials 2013, 34, 10278-10286. [CrossRef]

28. Yang, H.; Yang, S.; Kong, J.; Dong, A.; Yuab, S. Obtaining information about protein secondary structures in aqueous solution using Fourier transform IR spectroscopy. Nat. Protoc. 2015, 10, 382-396. [CrossRef]

29. Sutherland, I.W. The biofilm matrix-An immobilized but dynamic microbial environment. Trends Microbiol. 2001, 9, 222-227. [CrossRef]

30. Laverty, G.; McCloskey, A.P.; Gilmore, B.F.; Jones, D.S.; Zhou, J.; Xu, B. Ultrashort Cationic Naphthalene-Derived Self-Assembled Peptides as Antimicrobial Nanomaterials. Biomacromolecules 2014, 15, 3429-3439. [CrossRef]

31. Veiga, A.S.; Sinthuvanich, C.; Gaspar, D.; Franquelim, H.G.; Castanho, M.A.; Schneider, J.P. Arginine-rich self-assembling peptides as potent antibacterial gels. Biomaterials 2012, 33, 8907-8916. [CrossRef]

32. Salick, D.A.; Kretsinger, J.K.; Pochan, D.J.; Schneider, J.P. Inherent antibacterial activity of a peptide-based beta-hairpin hydrogel. J. Am. Chem. Soc. 2007, 129, 14793-14799. [CrossRef]

33. Zhou, C.; Li, P.; Qi, X.; Sharif, A.R.M.; Poon, Y.F.; Cao, Y.; Chang, M.W.; Leong, S.S.J.; Chan-Park, M.B. A photopolymerized antimicrobial hydrogel coating derived from epsilon-poly-l-lysine. Biomaterials 2011, 32, 2704-2712. [CrossRef] [PubMed] 
34. Barth, A. Infrared spectroscopy of proteins. Biochim. Biophys. Acta Bioenerg. 2007, 1767, 1073-1101. [CrossRef] [PubMed]

35. Kaberova, Z.; Karpushkin, E.A.; Nevoralová, M.; Vetrík, M.; Šlouf, M.; Dušková-Smrčková, M. Microscopic Structure of Swollen Hydrogels by Scanning Electron and Light Microscopies: Artifacts and Reality. Polymers 2020, 12, 578. [CrossRef] [PubMed]

36. Brown, M.L.; Aldrich, H.C.; Gauthier, J.J. Relationship between glycocalyx and povidone-iodine resistance in Pseudomonas aeruginosa (ATCC 27853) biofilms. Appl. Environ. Microbiol. 1995, 61, 187-193. [CrossRef] [PubMed]

37. Ansari, M.A.; Albetran, H.M.; Alheshibri, M.H.; Timoumi, A.; Algarou, N.A.; Akhtar, S.; Slimani, Y.; Almessiere, M.; AlAhmari, F.; Baykal, A.; et al. Synthesis of Electrospun $\mathrm{TiO}_{2}$ Nanofibers and Characterization of Their Antibacterial and Antibiofilm Potential against Gram-Positive and Gram-Negative Bacteria. Antibiotics 2020, 9, 572. [CrossRef] [PubMed]

Sample Availability: Samples of the compounds are not available from the authors.

Publisher's Note: MDPI stays neutral with regard to jurisdictional claims in published maps and institutional affiliations.

(C) 2020 by the authors. Licensee MDPI, Basel, Switzerland. This article is an open access article distributed under the terms and conditions of the Creative Commons Attribution (CC BY) license (http://creativecommons.org/licenses/by/4.0/). 